\title{
Islet Cell Adenoma
}

National Cancer Institute

\section{Source}

National Cancer Institute. Islet Cell Adenoma. NCI Thesaurus. Code C65184.

A benign endocrine neoplasm arising from the pancreas. It is separated from the normal pancreatic tissues by a thin collagenous capsule. It may secrete a hormone (e.g. insulin, gastrin) or it may be non-functional. 